\title{
ОСОБИНЕ РАЗГОВОРНОГА СТИЛА У ЗБИРЦИ АНЕГДОТА УЧИНИ МУ ЋЕФ ПОСА' МУ НЕ СВРШИ РАДОСАВА ЦИЦА ПОПОВИЋА
}

\begin{abstract}
Траже се одговори на питање: да ли се језик ове збирке може сматрати записаним говором Поповићева завичаја (подгорички стилски идиом и говор Куча), са типичним обиљежјима усменог разговорног функционалног стила; или су пишчеве обраде усмених верзија шаљивих прича, средствима писаног разговорног стила, донекле дотјеране, дајући тексту примјесе књижевне вриједности?

Кључне ријечи: Радосав Цицо Поповић, разговорни стил, анегдоте/шаљиве приче, подгорички стилски идиом, говор Куча, писани израз, правопис.
\end{abstract}

Збирку Учини му ћеф поса' му не сврии Радосава Цица Поповића чине 373 из свакодневног живота извучена и преписана истинита догађаја - различитог обима, вриједности, занимљивости и степена необичности. Не могу се најтачније ни класификовати - јесу ли то вицеви/шале, анегдотоидне приче, духовити записи или чисте анегдоте, како смо их у наслову рада назвали, или су у питању неке граничне форме ${ }^{1}$. Можда је дилему најбоље разријешио сам аутор, ${ }^{2}$ који је испричане догодовштине назвао марифетлуцима (марифетлук

*jmisko@ac.me

1 За прецизно разграничење није од велике помоћи ни досадашња лингвистичка литература о датој проблематици: „традиционална граматика није показивала много занимања за виц - јер виц у језичноме смислу (...) није препознат као нарочито интригантан предложак”, то су „сразмјерно кратке и граматички незахтјевне језичне структуре” (Бадурина и други 2019: 223, 230).

${ }^{2}$ Радосав Цицо Поповић није необразован човјек, био је генерални директор биоскопа „Култура" у Подгорици, у два четворогодишња мандата од 1980. до 1988. године предсједник Удружења биоскопа Југославије и члан Управног одбора некадашњег „Југославија филма”. И није ово његова једина књига (објавио је десетак, сличне тематике) - за збирку духовитих записа Цицо против Радосава предговор је написао редитељ Лордан Зафрановић. Себе је сматрао Подгоричанином, затим Кучем, а кучко село Врбицу (10-ак километара сјевероисточно од Подгорице) најужим завичајем. 
< apaп. ma'rifa - лукавство, препреденост, мајсторија, домишљатост). Додуше, своје записе лично је називао и шалама - „љутили се неки моји добри пријатељи, Зећани, што стално причам ове шале о Зећанима", жали нам се у причи Зетске овце (74). Релативно чврстим и затвореним језичким структурама, колоквијалним стилом, долази се до зачудних исхода, са пожељно је комичним ефектом. Све те приче везане су за конкретан комуникацијски догађај, неусиљена ћаскања између блиских особа, гдје је казивач најчешће свједок, често и учесник - он или члан његове уже и шире фамилије, многе му је неко испричао, а аутор се потрудио да их вјерно пренесе, баш како их је чуо или као што у усменој причи Подгорице и околине, а поједине и много даље, живе. Дакле, учесници такве комуникације обично су у присним односима па се умјесто правим именима у различитим марифетлуцима ословљавају надимцима, именима од миља, како су углавном једино и познати у својој средини. Употреба хипокористика, као израженом карактеристиком збирке, личности прича још више приближава - и међусобно, и са преносиоцем хумористичког догађаја Цицом. Да и ми употријебимо надимак, јер се његово крштено име Радосав, наслијеђено од свога дједа, ријетко у овој књизи употријеби. Вељо, Биро, Вушо, Ћићо, Шако, Дуљо, Аљо, Зеко, Чоки, Љепо и друге Цицу блиске особе појављују се у омиљеним подгоричким састајалиштима - башти хотела „Црна Гора”, ресторану „Два крапа”, башти биоскопа „Култура”, у златним годинама филма, кафани Радомира Мијовића на Биочу итд. чији ће их сусрети, дружења и духовите досјетке увести у књигу Радосава Цица Поповића Учини му ћеф поса' му не сврии. Но, његови омиљени ликови: судија за прекршаје Лука Шкури, Божо и Цено, обућари, угоститељ, боксерски судија и шерет Душко Секулић, брицо Ајдар, професор Гимназије Блажо који се често изражава у стиховима, с обавезном римом: Слабе су ни наде/да ти будеш чељаде (Чељаде, 81 ); Нека вас је срам што вам је овакав божји храм (Римовање, 27), Анђелко, сликар из Херцег Новог, Мишко возач и многи други нијесу само у Подгорици - радње се одвијају и у Београду: на Теразијама, Мажестику, Душановом конаку; а неки од њих су на Цетињу, Бару, Тивту, Зети, Црмници или најтоплијем пишчевом кутку - завичајним Кучима и селу Врбици.

Разговара се о свему и свачему, нема табу тема, блиске особе изговоре превише вулгаризама, а аутор их неселективно, нефункционално, без добре мјере преноси. А какви би то сусрети били, ако се учесници са дозом хумора не дотакну историје, историјских личности - свога Куча војводе Марка Миљанова, краља Николе Петровића, похаре Куча, Јосипа Броза Тита, али и новијих политичара и личности - свјетских моћника: Блера. Холбрука, Фидела Кастра, а и локалних: бившег предсједника Црне Горе Вељка Милатовића, градоначелника Подгорице, Цетиња, народних хероја, министара бивших и садашњих итд. Записани разговори са дружења пријатеља, подразумијевају истинитост, то мора, без провјеравања, бити „гола истина”, како је једну причу насловио аутор (17). Такође се подразумијева да тако записани догађаји прођу без вријеђања и љутње, а није било увијек тако: „Тада се она љутила на мене, и то се дешавало прије десетак година" (Задња банда, 
16), као реакција на његову збирку сличног садржаја Можемо ли дво'ица на двије карте. Без обзира на искрена дружења и међусобну толерантност актера шаљивих прича збирке Учини му ћеф поса' му не сврши, с обзиром на садржаје појединих, не вјерујемо да је и њено објављивање (2000. године) прошло „сасвим мирно”.

Нема сумње, а то ће се даљим анализама и показати, језик збирке прича „Учини му ћеф, поса' му не сврии” може се сматрати записаним говором, и то подгоричким идиомом, (вернакулар градске средине) који досад није покривен озбиљнијим дијалектолошким истраживањима. Већина шаљивих прича из ове збирке, прије добијања писаног облика, имала је извјесни период усменог постојања, када су разне досјетљиве згоде и незгоде о (не)обичним људима у разним варијантама причане и преношене. Управо се због тога, и због карактеристика усменог модела, због готово дословце преписане усмене верзије анегдотоидне приче, њихова садржина и комична поента лако памти и преноси. Дакле, већина прича из ове књиге имају карактер усменог начина изражавања типичног за разговорни функционални стил. То су незванични, неусиљени, спонтани и дијалошки начини изражавања, при чему се користе сва језичка средства и поступци који карактеришу разговорни стил: користе се разговорне ријечи, облици и конструкције; понекад се свјесно умећу жаргонизми, на синтаксичком плану има доста елиптичних реченица (Тошовић 2002: 381, 386). Развија се, као и у усменој реализацији, у доста врста: „у њиховој основи се налази специјалност (приватни круг, продавница, ресторан, хотел, кино, посао, пијаца, жељезничка станица, аеродром, пошта...), темпоралност (јутро, дан, вече, ноћ, зима, љето), дијалогизираност (разговор са самим собом или са више особа)" (Тошовић 2002: 381).

Рекли смо, неке приче из збирке је тешко везати за одређени жанр, с обзиром да су ограничене на једну сцену која нагло кулминира с поентом, у чијој се структури препознају три дијела, неке припадају чистом вицу: „Основна је структура вица тродјелна (А) увод у којему се описују (не)обичне околности, ситуације, онога што се догађа; (Б) приповједни дио вица, који се може остварити било у релативно опсежну приповиједању (често градација), било у нултој нарацији као успорењу (драмска станка); (В) поента вица којом се виц разрешује и у којој се остварује комичан ефекат" (Бадурина и други 2019: 225).

Кад год то „говоритељу” затреба, он употријеби и облике стандардног језика и домаћих говора - рекли бисмо, језик анегдота чине супстандардни идиоми, тј. укрштање органских идиома (подгоричког и завичајног кучког) са неорганским књижевним језиком. ${ }^{3}$ Казивач приче, било да је учесник или свједок комуникацијском догађају, или су то романтично-забавне досјетке које му је неко испричао, не улаже озбиљан представљачки напор да нас уведе у садржај, дијалошке склопове и хуморне пасаже који слиједе - изостала је

${ }^{3}$ „У органске идиоме спадају углавном рурални месни говори и дијалекти, док супстандардни идиоми укрштају особине органских идиома и књижевног језика и углавном су везани за урбане средине (најчешће подразумевају разне типове жаргона, урбани разговорни језик и шатровачки говор)" (Ковачевић 2016). 
права љепота и сажетост наративног исказа, зато ни књижевни учинак ових прича није велики. Ипак, постоји књижевни минимализам - за оживљавање казивачке форме, за дијалошке склопове који треба да доведу до основног циља - комуникацијског сусрета друштва, до комичног ефекта, у одређеној мјери се препознају и елементи књижевноумјетничког стила, и неких других стилова. У таквим монолозима (уводима у шаљиве приче) донекле се ремети природни разговорни функционални стил и извјесном обрадом постиже се званичност, чиме „сирови говор” неких прича добија примјесе стилизованог. ${ }^{4}$

У овим дјеловима прича, у проширеним монолозима, аутор се служи приповједачким временима, а два су му омиљена, са готово истим степеном учесталости - презент и крњи перфекат. Дајемо нешто примјера.

Презент: Брано Булатовић учи основну школу и добар је ђак (Сабирање, 17-18),Улазе усплахирено браћа Рогошићи (Саобраћајна, 23), Милиционер у цивилу, трчи за неким око Сахат куле. Срете га колега позорник (На вријеме, 24), Трешти музика на телевизору (ТВ неваљалко, 47), Сједимо испред сале, наилази Небојша, а Јово га пита (Травник, 70).

Крњи перфекат: Божо прилегао. Ставио ципеле испред врата. Дошли другови и цукају на врата (Одсутан, 19), Зеку бријачу дошао неки Бјелопољац (Монтажна глава, 26), Кренула екипа ТВ на задатак (Гаравост, 32), Покојни Шаћо Марић правио кућу (Просци, 36), Дошао неки мајстор у биоскоп да поправља ролетне (Поздрав покојници, 14), Пошли ја и Гора код мог колеге Рада Поповића да му понесемо књигу (Задња банда, 16), Окупили се пријатељи у „Два крапа” (Ловачка, 18).

Обичан је и перфекат: Момо није, бог зна, био неки ђак, али је завршавао школу на вријеме (Одозад, 12). Даница је удата за Ивановића на Златици, код добрија (Не) сврћите, 12), У тај вакат био је обичај да се на сваки сто стави по корпа јаја за мезу (Мућак, 20), Предсједник Милатовић волио је Ива Милетина, а богоми Ивово вино више (Покојни отац, 30-31), Имали смо једнога стрика у Врбасу (Гуслање, 33), Мој рођак Миљо живио је у насељу код војног логора у Маслинама (Тркачица, 34-35), Често је сједио у Кучкој кафани (Наопачке, 50).

С обзиром на обичност аориста у завичајном кучком говору његова је употреба у причама из Поповићеве збирке унеколико снижена: Први курир поче причу (Бистрина, 39-40), Једног дана виђе на вратима закачен рачун за струју (Неплатиша, 48), Кад му овај рече (...) ови се забезекну (Мајка, 38-39), Рекоше му: ено ти га они чича (Слика и прилика, 99), Тако и би (Навика, 114-115, Гужва, 138), Договорише се и то испоштоваше једно вријеме. Невјеста се мало поисправи, погледа на календар (Сурбота, 136), Поскакасмо ми у вис! (Трупица, 125-126). Посиједаше, наједоше се и напише (Партизански четници, 139). Међутим, у прецизно записаном говору, у дијалозима, употреба аориста се интензивира: Што му би? (Узречица, 35-36), Би ли ти, Велиша, у четнике? (Телефон у гробници, 121-122), Ови мој даде ми 100

\footnotetext{
${ }^{4}$ Разговорност може у неким писаним текстовима бити и умјетнокреирана, подсјећати на разговор (Ковачевић/Бадурина 2001: 55).
} 
динара. Ништа не рече за бензин (Бистрина, 39-40), То и урадисмо (Задња банда, 59-60), Изгубисмо Стану (Телеграм, 64), Ја крепах (Није то исто, 66), Ја дадох сто марака (Поткусурио га, 71), Што ме, Иво, не причекасте? (Колега, 72), Спушти завјесу, Гара, е се убих, нагрдих (Сликање, 108), Е покрепасмо (Сурбота, 136), Ишћерасте ли овога рођака и из љуђи ка из Партије? (Ћерање, 53).

Имперфекат је необичан, скоро по правилу везан за глагол хтјети: Ја оћах да питам (Ћерање, 53), 'Оћах да те питам (Зетске овце, 74), Он 'оћаше да се куне (Ожалошћен, 74-75); усамљен је примјер имперфекта од зборити: Збораше у свој вакат Ђоно (Гостопримство, 94).

Врло погодна форма за изражавање доживљеног, динамичног и хронолошки датог слиједа догађаја у црногорским, и уопште говорима српског језика, јесте приповједачки императив који се у причама ове збирке никако не употребљава. Понекад се у тој функцији, за постизање особите експресивности, појави футур I - Једног дана ће комшија Јован: 'Ајде сине Мићанов, 'ајде де, 'ајде на чесму Новакову (Чесма, 34), Долази супа пилећа, како и треба, кад ће ти Анђелко (Арго јуха, 86); а особита експресија постигнута је употребом приповједачког потенцијала у причи Насљедни аутобус (122): Купио би бурек, сјео у аутобус, иза шофера, и право у Бјелопавлиће. Кад би доша у Даниловград, није излазио из аутобуса но би ту изио бурек.

Хронологија догађаја, љепота израза, динамичност догађаја у причању прошлих радњи некада није изведена у духу правилног (или логичног) слагања глаголских времена, како је у примјерима - презент + аорист + презент: Баба Стефа, по обичају, упали свијећу и чека госте, кад у тај трен нестаде струја. Баба улази у собу и пита Ива (Тамјан, 67); перфекат + аорист: Провуковали су испод Ћубина камена, па му ништа не помога! (Ћубин камен, 114); крњи перфекат + презент: Завршио школе у Београду. Запосли се у некаквом бару ка' избацивач (Тако некако, 30); перфекат + презент: Једнога дана, збиља, Милета ми је требао, и уђем у кафану (За трпезом, 75). Свакако, овакав избор и редосљед глаголских облика за означавање прошлих радњи не доприноси ни љепоти наративног израза ни сажетости описа.

Потпуну везаност разговорног функционалног стила Поповићевих шаљивих прича за друге стилове, а највише књижевноумјетнички, чине њихови наслови, који су често веома инвентивно дати. Прича је дотјерана средством писаног израза, насловима попут: Дочек са фалинком (14-15), Коњски поглед (15-16), Мућак (20), Волови (21), Обућарска (21-22), Де Сикини потомци (23), Монтажна глава (26), Замало мр (26), Блесавлук (27-28) и други наговјештај су необичности приче, успјешна припрема за истинити комични догађај из свакодневног живота који слиједи. Неки су плод ауторове особене творбе ријечи, тако да се у насловима налазе и тзв. „лексеме метеорити”, створене само за дату прилику, а ван страница ове књиге, тешко да ће икада бити употријебљене. Да поменемо само неке: Поткаповић (11), Солитерац (17), Ћумурација (37), Скакарина (41), Нотално (45), Побрканција (46), Ћелестонке (54), Поспаница (61), Тутурикач (87), Пированија (88), Мравомаз (106). 
Ипак, шаљиве приче из ове књиге имају и неке препознатљиве особине писаног разговорног стила, гдје је исказ - посебно пишчеви уводи, али и креирани дијалози - донекле дотјеран, посебно употребом различитих правописних средстава. Писани израз Радосава Цица Поповића одликују разне фонетске метаплазме - најчешће је одузимање, при чему се недостајући дио ријечи означава апострофом: Нит' смијем нит' умијем (Бржи од ваљка, 30), Виде га Цетињани ђе се сага' (Ишијас, 14), Овога чојека неће имат' ко дочекат' (Дочек с фалинком, 14-15), Много му се 'ита, 'оће на некакву коференцију (Монтажна глава, 26), Да' ни, невјеста, још по једну! (Још по једну, 35), Имамо кол'ко год 'оћеш (Тврдоћа, 38). Међутим, правописна коректност, гледано у цјелини збирке, у Поповићевим причама није изведена до краја - тако ни писање апострофа, па су обични и примјери у којима окрњене форме, које одговарају стању у народном говору, нијесу обиљежене овим правописним знаком (посебно супинске форме инфинитива): Можемо ли, мајсторе, опрат ауто? (Ауто перут, 32-33), Попите по једну, по двије, и ајд здраво (Сад смо квит, 130-131), Хрче покојни Лука, заспат се не може (Трупица, 125-126), Морали су повјероват (Шупљоглавост, 125), Оли платит, Велиша, по кафу? (Муштулук, 120-121), Ђеца ти немају што јес! (Краљева милост, 116-117), Ђедо, оћу да звиждим! (Стари бонтон, 86).

За прецизирање унутрашњих односа у реченици, односно за издвајање појединих дјелова реченице, аутор с пуно осјећаја употребљава зарез: Једне ноћи, таман пануо први мрак, кренула она у комшилак (Неконтролисано, 12), Пукао некакви сјевер, очи да извади (Вјетар у наставцима, 15), Народни посланик, кум овога рођака, тобош, интервенише код Удбаша (Коњски поглед, 15-16), Благоти, газди „Два крапа”, дешавало се, кад госту доносе супу, да му прст упане у њу. По обичају, ево супе, али и прст у супи (Прстомјер, 21). Умјесто зареза, посебно када из усменог говора жели пренијети дужу паузу или промјену дикције, зналачки се употријеби црта: Вукчевићи, сви од реда, ка на штанц машину, сићушни, сем Бранов син - висок (Солитерац, 17), Наиђе професор Блажо - усправан, кратког корака, ошишан и са шеширом на глави (Премјеравање, 28), За ове ван овија само - добар је (Градација, 50).

И вокатив се, сходно правописним правилима, од других реченичних дјелова одваја зарезом: Откад си, чојку, иза мене? (Неконтролисано, 12), Пољуби се, сине, са овом тетом (Задња банда, 16), Није ми, чоче, то тешко (Гола истина, 17), Донеси ни, Зарија, четири воде (Волови, 21), Пушти, Бобо, сине (Великоножна, 49). Међутим, ова правописна коректност у књизи није до краја спроведена - обје могућности (писање зареза и његово изостављање) појављује се у истим причама, чак и у истим реченицама: Шта је ово стрико? Не, вели стрико, но сјевер најгоре врсте. Шта је ово сад, стрико? Сјевер, мој сине. Како, стрико, сјевер и они прекјуче и ови данас? (Вјетар у наставцима, 15).

Бројност употријебљених узвичних реченица свједочи о наглашеној емотивности ауторовој у казивању прича: Ајде, дабогда све ви у ову државу здраво било ка ови мој коњ! (Коњски поглед, 15-16), Е, он је, приватно, за мене ништа чојек! (Човјекомјер, 22), Заврши неке послиће и врати се, 
кад нема аута! (Пуштите ме..., 25). Штавише, појачани степен зачудности појединих сцена из прича Поповић означава факултативним стилистичким средством, тј. писањем два знака интерпункције - узвичника и упитника. Упитаност и чуђење, у исто вријеме, много је чешће обиљежена слиједом ? + !: Нијесам дома! Како нијеси кад ти ево ципеле испред врата?! (Одсутан, 19), Није ми јасно, куме, јесу ли ови твоји пријатељи заклали прасе или стоногу?! (Пршута, 35), Јесам ли вас увјерио да сам га добро измјерио?! (Премјеравање, 28); али је потврђен и обрнути ред: Фала ти Гано, онакве воде нијесам пио у животу, но ми реци како ти се могу одужит!? (Резанци, 124), Што си навалио на ту сирену, ка да си завршио музичку школу!? (Музичко образовање, 137).

Проблеми с правописом нешто су присутнији у писању рјечце не: Ја је богоми дома водит' не ћу! (Поклон, 45), Паркирао се на не дозвољеном мјесту (Муваш, 25-26), Узме унук двије карте, а ђедо неда (Још по једну, 35), Не ћеш, ни да јаки бог, одит без ручка (За трпезом, 75), А што чоче, немош ти мене вјероват (Ловачка, 18); једном је и 2. л. мн. аориста глагола бити неправилно написано одвојено: Би сте ли ме, момци, могли научит' (Оно изнутра, 131). Понекад ни асимилације нијесу извршене - по звучности: Нека разлику изкомпензира (Компензација, 93); и мјесту образовања: Ту се лијепо исчеститају (Осушени измет, 19-20). Очувана је сугласничка група дс: Друже Предсједниче (Дочек с фалинком, 14-15), Дошао на одсуство (Војни речник, 36), Пођоше представници фабрике (Камени клинци, 61), Не представља се (Погрешна адреса, 109), Играм ти у ову представу (У фаху, 77); само је у једном примјеру, испадањем денталне оклузиве, упрошћена: Је ли ви ови пре(д)сједник Њемачке - пита Ратко (Крволочни, 77). Сугласничка група -дск- спорадично се пише у складу са фонетским принципом $(\partial c>u)$ : Како без љуцки? (Боцун, 57), док је -тск- написана без промјене - према морфолошком правописном принципу: Зетске овце (у наслову, 74). Гледано у цјелини, аутор води рачуна о правилном писању - у примјерима: Зоолог (у наслову, 106), Сад су најјаче земље на свијет' (Побијеђени побједник, 90) лексема зоолог и суперлатив најјачи се, другачије од изговора, у писању фонетизирају.

Аутентичност комуникационог догађаја постиже се изнад свега слободом употребе језика између учесника, који је у односу на кодификациони стил изговора обично граматички неисправан и нечист, са доста дијалектизама, провинцијализама и жаргонизама, што носи „допунску информацију о социјалном поријеклу говорног лица, његовом културно-образовном нивоу и степену познавања норми стандардног језика (...) Комуникатори су различити (...) по интелектуалним могућностима, моралним, националним ${ }^{5}$, вјерским и другим назорима и сл.” (Тошовић 2002: 381, 400). У Подгорици су једни поред других, односно једни с другима, живјели припадници разли-

\footnotetext{
5 Често је припадност одређеној заједници и познавање њене културе важно за правилно разумијевање шаљиве приче, односно „нужност посједовања одређених позадинских знања која су посредована ширим друштвеним, културним и повијесним контекстом” (Бадурина и др. 2019: 223).
} 
читих вјера и нација (хришћани и муслимани), у Кучима, завичају аутора ове књиге, на међи с Албанијом, Кучи и Малисори су вјековима заједно, „пријатељују" (мјешовити бракови), збијају шале, свађају се и мире, о чему свједоче и неке приче из Примјера чојства и јунаштва Марка Миљанова. Личност Албанца језички је обиљежена устаљеним идиоматским изразом „таком Бога" - Прегледа га доктор и констатује да му је лијеви бубрег мало начет, а десни савршено ради. Малисор каже доктору: Тако м' Бога, доктор, за ови лијеви нијесам зна, а десни сам извадио ево година! (Нестао орган, 45-46), Доша Шиптар у Бар и на шалтеру тражи карту до Подгорице. Благајница га пита: „Хоћете ли повратну карту?” „Не, таком Бога, дај неповратну!” - рече Шиптар (У једном правцу, 118-119). И не само Албанци - и обичном човјеку препознатљивим изразима карактеришу се и други народи, који су у овој књизи предмет понеких шаљивих прича: Дође некакви Француз, комедијаш, који је скупљао загонетке, питалице и шале. У пекари, с врата: Бонжур, мистер Мило! Бонжур га и тебе. Бонжур мисје комедиограф. Француз: Мисје Мило, ја не зна! (Квиз из Киш-махале, 112-113). Снајки Добрили Србијанки остала је понека ријеч из свога рода - ниси, видео (Одвикао се, 52). Да би се дочарао говор подгоричких муслимана понекад долази до фонолошке неутрализације и неразликовања гласова - 4 и $\hbar$ : Имате ли јућерашњег 'љеба? (Тврдоћа, 38); н и њ: Ња ви га - каже Шућо Слачак друговима (Шокирање, 76), а ни једна ни друга црта не карактерише говоре Подгорице и околине - ни хришћана ни муслимана. Морате бити „добри другови, ка’ браћа”, као што су били риболовци Брано Вучевић и брицо Ајдар, да би предмет шале биле национално и конфесионално осјетљиве теме, попут прича: Гола истина (17), Мајка (38-39), Саучешће (58), Немо’ више додит' (118), Поткусурио га (71) и још неких.

Одступања од норме нијесу резултат ауторовог незнања и необразованости, дакле она нијесу погрешка, већ његова свјесна намјера да што вјерније пренесе конверзацију - у захукталости говорног (и писаног) ритма на те елементе се не обраћа пажња. Одступања од норме нијесу погрешка, већ његова одлика. Употребом сниженог стила писац је настојао да у дијалогу учесника комуникацијског чина сачува обиљежја мјесних говора. Међутим, он ријетко употребљава црте које су, из перспективе цјелине црногорских говора, одвећ усколокалне. На примјер, у говорима црногорско-албанског пограничја, нарочито у ауторовим Кучима, изгубљена је опозиција између сонаната $л$ и $љ$, односно испред вокала предњег реда $e$ и $u$ глас $л$ се изговара умекшано, те се изједначава са фонемом љ. Ова на овом простору препознатљива особина, рођеном Кучу Цицу Поповићу „промакла” је само у неколика примјера - лексички ограниченом љевор (< левор - револвер): Љевор иза паса поша' на крај собе. Што, рођаче, не узмеш ови љевор, па ме убијеш? (Више од јунаштва, 127); Јеси ли има љевор? (Адемовица, 54); и у вицкастом говору Зарије из Дољана на „гробу свога магарца”: Муље моје, (< муле - магаре) / дошло ти је друштво твоје, / није један но двојица, / ка бирана четворица (Сахрана 26-27). Сви вокали на крају ријечи могу бити назализовани до мјере да представљају потпуни назални вокал, чист назал - то је типична црта у говору Куча. Ова у 
језику Анегдота избјегавана особина у једној је причи искоришћена за веома инвентивну комуникацију комшија: Питају Милана из Куча: - Ђе то идеш? - Милане! (он пјан ка метла). - Идем на посан. - Тако ми Бога ти си добро напосан, немаш што одит! Инвентиван је и наслов приче - Пресаухован (73). Народни говори, па и говори Подгорице и Куча, показују изражену склоност ка губљењу денталних оклузива $m$ и $\partial$ у позицијама сандхија: уколико се ови гласови нађу на крају прве ријечи, а на крају друге неки њима слични консонант (и не само тада) тешкоћа изговора таквих сугласничких група отклања се пропуштањем изговора ових дентала. Незаустављивост говорног ритма шаљиве приче Саобраћајна (23) обезбиједила је потврду и ове особине: Са' ћу ја ово да раскрчим; а писање апострофа, на мјесту сугласника $\partial$, искључује могућност штампарске грешке или омашке ауторове.

Нема сумње, у писаном варијетету анегдотоидних прича Радосава Цица Поповића препознају се многи елементи разговорности, при чему се аутор трудио да што вјерније пренесе истинити догађај. Зато су његове личности сачувале народски начин причања и особине мјесног говора - доминирају језичке црте карактеристичне за подгорички стилски идиом и сусједни локални говор Куча, који јесу блиски, али и по много чему различити. Говорно лице не нарушава норму ради стварања изражајности, упечатљивости, већ из чисто комуникативних побуда. Ипак, извјесном пишчевом обрадом текста усмене верзије прича (садржина многих од њих се дуже вријеме преносила усменим путем), у циљу постизања љепше комичне поенте чисти народни говор понекад добија и примјесе стилизованог - на тај начин Поповић је остварио извјесни књижевни минимализам. Гледано у цјелини, аутор води рачуна и о правилном писању, што није увијек довело до правописне коректности.

\section{ИЗВОРИ}

Поповић 2000: Радосав Цицо Поповић, Учини му ћеф, поса'му не сврии (Подгоричко-кучки марифетлуци), Подгорица: Библиотека Посебна издања.

\section{ЛИТЕРАТУРА}

Бадурина и др. 2019: Лада Бадурина, Никола Палашић, Иво Прањковић, Стереотипи у вицевима, Сборник с доклади от Четиринадесетите международни славистични четения, София, 26-28 април 2018 г., Том 1, Езикознание, Университетско издателство „Св. Климент Охридски”, 223-232.

Кликовац 2002: Душка Кликовац, Из проблематике функционалних стилова у српском језику. Кюижевност и језик, 49, 9-26. 
Ковачевић/Бадурина 2001: Марина Ковачевић, Лада Бадурина, Раслојавање језичне стварности, Ријека: Библиотека Домети, Нова серија, књ. 138, Издавачки центар Ријека.

Ковачевић 2016: Милош Ковачевић, Књижевни и разговорни језик, Политика, 11. 10. 2016.

Тошовић 2002: Бранко Тошовић, Функиионални стилови, Београд: Београдска књига.

Miodrag V. Jovanović

\author{
THE CHARACTERISTICS OF THE CONVERSATIONAL WRITING STYLE \\ IN THE VOLUME OF ANECDOTES UČINI MU ĆEF POSA' MU NE SVR ÍI \\ COMPILED BY RADOSAV CICO POPOVIĆ
}

\begin{abstract}
Summary
Most of the humorous tales from this collection share the features of oral communication, typical of the conversational style. Due to the characteristics of the oral model, the oral version of their content which was copied almost verbatim, the comical punch-line is easily remembered and conveyed. That is why the author's characters retained their folk way of conversing and the features of the local speech - linguistic features characteristic of the Podgorica stylistic idiom dominate, along with those of the neighboring speech of Kuči, which do share many features in common, but also differ in a variety of ways.

In the attempt to bring the storytelling to life, and ensure segments of dialogue will produce a comic effect, to a certain extent we can still recognize the elements of the literary artistic style, and some other styles as well. Still, humorous stories from this book also have some recognizable features of spoken conversational style, where the proposition - especially the writer's introductions, but also the invented dialogues - have somewhat been polished, especially through the use of various spelling forms. The author is careful to adhere to the rules of proper writing, which did not always lead to correctness in spelling.

Kay words: Radosav Cico Popovic, conversational style, anecdote/comical story, Podgorica stylistic idiom, speech of Kuči, spelling.
\end{abstract}

